\title{
Characterization of Polish Phytophthora lacustris Isolates Obtained from Water Environments
}

\author{
Katarzyna J. Nowak ${ }^{1 *}$, Aleksandra Trzewik', Dorota Tulacz ${ }^{2}$, \\ Teresa Orlikowska ${ }^{1}$, Leszek B. Orlikowski ${ }^{1}$
}

'Research Institute of Horticulture, Konstytucji 3 Maja 1/3, 96-100 Skierniewice, Poland ${ }^{2}$ Institute of Biochemistry and Biophysics Polish Academy of Sciences, Pawińskiego 5a, 02-106 Warsaw, Poland

Received: 26 June 2014

Accepted: 23 September 2014

\begin{abstract}
P. lacustris sp. nov. (formerly known as Phytophthora taxon Salixsoil) was first isolated in 1972 in the UK and then in many other European countries, including Poland. The aim of this work was a morphological, physiological, and genetic characterization of the P. lacustris isolates by means of the daily growth rate, mycelium morphology, and generative and vegetative structures, depending on the temperature of incubation and growth media. In addition, the ability to colonize willow shoots and leaves was estimated.

Out of 114 isolates of $P$. lacustris obtained from water habitats located near plant nurseries in central and southeastern Poland in 2007-10 that were identified on the basis of molecular tests which showed high diversity in colony growth patterns and daily growth rates, 10 groups were separated by means of Duncan's test. Representatives of these 10 groups together with three reference isolates - P. lacustris P245 as the holotype, P. gonapodyides CBS 117380 as a specimen most closely related phenotypically to $P$. lacustris, and $P$. cactorum as a positive control of forest trees' pathogen - were researched.

Great heterogeneity in the growth rates and morphology of mycelium, as well as in the structure of zoosporangia and hyphal swellings, were observed. Moreover, the isolates differed in their ability to colonize the willow leaves and shoots in the in vitro tests. Some correlation may be found between the daily growth rates and colonizing abilities, and between the daily growth rate and the dimension of the sporangia. Also, a large genotypic variation between the isolates based on the fingerprint patterns generated by molecular techniques (RAPD and ISSR) was obtained.
\end{abstract}

Keywords: morphology, Phytophthora lacustris, colonization, ISSR, RAPD

\section{Introduction}

During the last decades Phytophthora genus has become increasingly important in plant pathology and environmental sciences. Development of molecular techniques and the availability of the DNA sequences enabling markers designing $[1,2]$ caused a rapid increase in the detection and identification of Phytophthora species in plants, water,

*e-mail: katarzyna.nowak@inhort.pl and soil. Each year, a growing number of newly described species, also from those deposited for years in collections, which currently increased to 124 , has been noticed [3].

The destructive property of $P$. infestans was already shown in the $19^{\text {th }}$ century, when an epidemic of potato blight in Ireland, known as the Great Irish Famine, caused mass starvation and the exodus of many to the North American continent. From this period dates the name of the genus - Phytophthora (plant destroyer). Never since has such a destructive action of Phytophthora been repeated 
Table 1. The average and individual (in brackets) sporangial dimensions of 10 Polish isolates of P. lacustris and P245.

\begin{tabular}{|c|c|c|}
\hline Zoosporangial dimensions $[\mu \mathrm{m}]$ & $\begin{array}{c}\text { 10 Polish isolates of P. lacustris } \\
\text { mean } \pm \mathrm{SD} \text { (min.-max.) }\end{array}$ & $\begin{array}{c}\text { P245 } \\
\text { mean } \pm \mathrm{SD}(\min .-\mathrm{max} .)\end{array}$ \\
\hline Length & $43.9 \pm 7.3(24.4-65.9)$ & $41.6 \pm 6.1(29-57.3)$ \\
\hline Width & $29.5 \pm 4.9(18-49.3)$ & $29.5 \pm 4.9(20.1-41.5)$ \\
\hline Length to with ratio & $1.5 \pm 0.19(1.11-2.4)$ & $1.42 \pm 0.15(1.19-1.9)$ \\
\hline
\end{tabular}

with comparable force, due to knowledge of prevention (crop rotation, resistant cultivars) and access to effective fungicides. However, the importance of Phytophthoras in today's agriculture is high because of increasing industrialization of crop production (large monogenotypic plantations) and almost unlimited spread of microorganisms between countries and continents.

P. lacustris is an example of a species that has recently attracted interest. It has been increasingly isolated from the rhizosphere, soil, and water [4]. Especially the separation of this taxon from similar $P$. gonapodyides has resulted in an avalanche of reports about its mass isolation from a variety of aquatic habitats, wetlands and nurseries [4-10]. P. lacustris belongs to the Clade 6, the group of species connected with water environment and trees, and tolerant of high temperatures $[11,12]$. Up to now P. lacustris has been isolated from open water resources in many parts of the globe, i.e.: in the U.S. states of Oregon [13], Alaska [6], Tennessee [14], and New York [15]; Italy [16]; in Yunnan province in China [17]; in Norway [18]; Ukraine [19]; in forest ponds in Poland [20]; and in rivers and ponds facilitating water for irrigation of nurseries [21]. The presence of this species in irrigation water taken from open sources or used in circulation cycles from water reservoirs is of particular importance because of the easy spread of propagules between the natural and agricultural environments, in both directions [12]. Proving that $P$. lacustris is an opportunistic pathogen will indicate a serious threat to agricultural crops and forest nurseries.

Taking into account the above reasons, we decided to characterize the isolates of $P$. lacustris obtained from rivers and ponds in central and southeastern Poland, which are water sources for irrigation of nurseries.

\section{Material and Methods}

In 2007-10, using submerged rhododendron and oak leaves as baits [22], 114 isolates of Phytophthora lacustris were obtained from rivers (PL5, PL6, PL8, PL10), ponds (PL1, PL4, PL7, PL9), and irrigation canals (PL2 and PL3) located near ornamental and forest nurseries in central and southeastern Poland (Fig. 1). The isolates were identified to species based on PCR amplification with the species-specific primers [5]. On the basis of the growth rate and colony morphology observed on the PDA medium they were divided into 10 groups. One isolate per group was selected for further characterization. The reference isolates $P$. lacustris

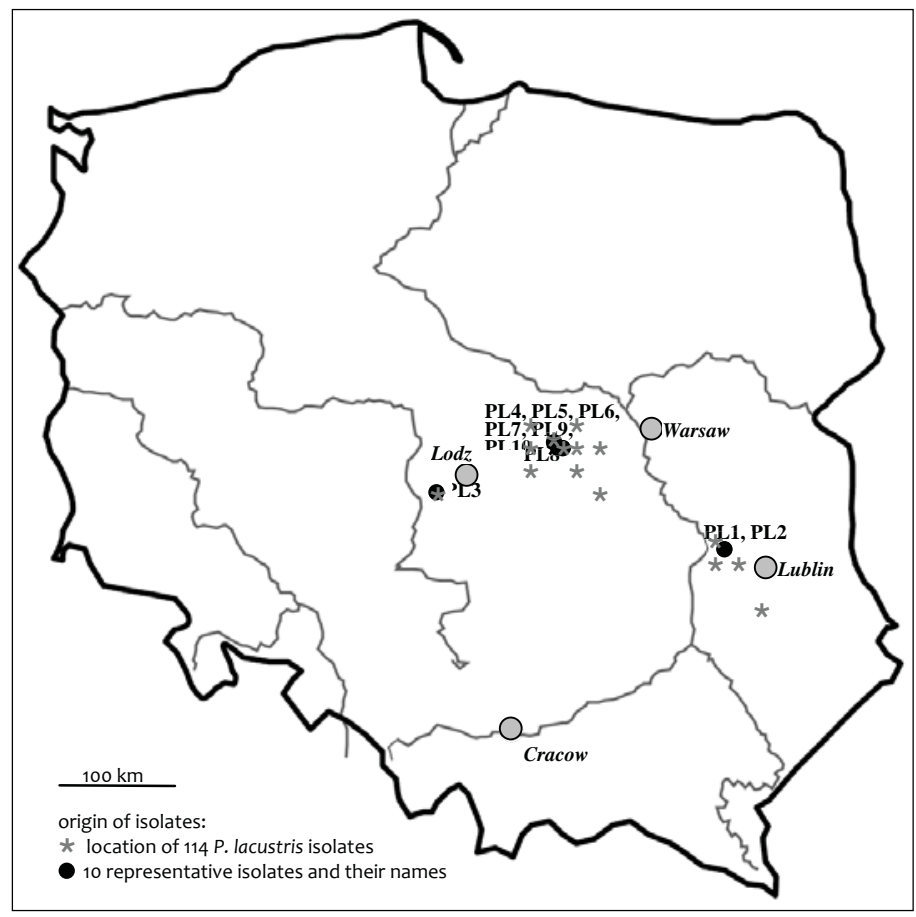

Fig. 1. The origin of the Polish isolates tested in this study. 

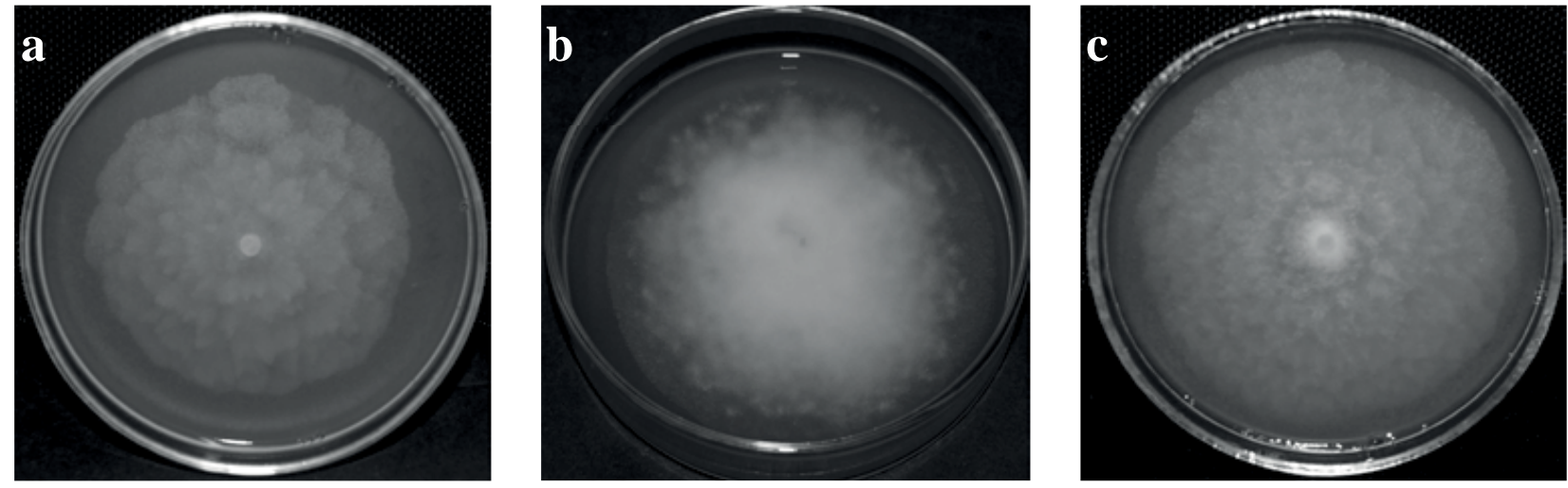

Fig. 2. Types of P. lacustris hyphae on CA: a-substrate, b-aerial, c- substrate and aerial only in inoculation zone.
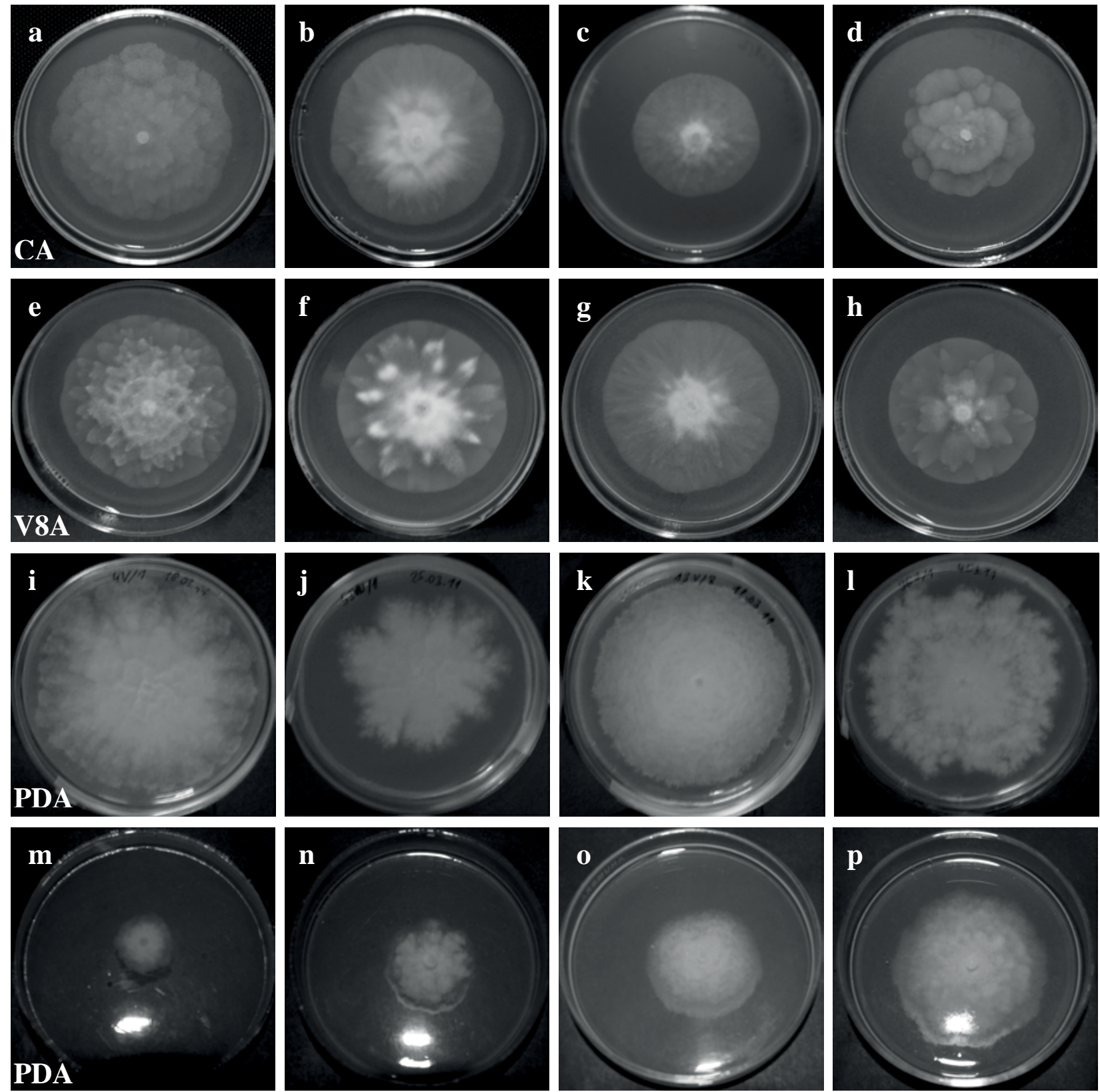

Fig. 3. Types of P. lacustris colony patterns on media CA (first row) and V8A (second row) after 7-day incubation and 14-day incubation on PDA (third and fourth row) at $25^{\circ} \mathrm{C}$. Differences in colony growth rate of individual isolates visible after 7-day incubation at $25^{\circ} \mathrm{C}$ on PDA. 
Table 2. The average and individual minimal and maximal (in brackets) radial dimensions of daily growth rate depending on medium and incubation temperatures of 10 Polish isolates of P. lacustris, P245 and P. gonapodyides.

\begin{tabular}{|c|c|c|c|}
\hline \multirow{2}{*}{$\begin{array}{l}\text { Growth } \\
\text { temperature }\end{array}$} & \multicolumn{3}{|c|}{ Daily radial growth rate $[\mathrm{mm} /$ day $]$ mean $\pm \mathrm{SD}$ (min.-max.) } \\
\hline & 10 Polish isol. of P. lacustris & $\mathrm{P} 245$ & P. gonapodyides \\
\hline & \multicolumn{3}{|c|}{ PDA } \\
\hline $6^{\circ} \mathrm{C}$ & $0.25 \pm 0.2(0-0.83)$ & $0.44 \pm 0.17(0.25-0.67)$ & $0.52 \pm 0.4(0.08-1)$ \\
\hline $10^{\circ} \mathrm{C}$ & $0.6 \pm 0.3(0-1.33)$ & $0.83 \pm 0.12(0-1)$ & $1 \pm 0.1(0.8-1.2)$ \\
\hline $15^{\circ} \mathrm{C}$ & $1.5 \pm 0.5(0.13-2.8)$ & $1.9 \pm 0.3(2.2-2.2)$ & $1.3 \pm 0.2(1.1-1.7)$ \\
\hline $20^{\circ} \mathrm{C}$ & $2 \pm 0.7(0.48-3.3)$ & $2.7 \pm 0.2(2.3-3)$ & $1.7 \pm 0.2(1.4-2)$ \\
\hline $25^{\circ} \mathrm{C}$ & $2.7 \pm 0.6(1.7-4.6)$ & $3.3 \pm 0.8(2.3-4.2)$ & $2.3 \pm 0.2(1.8-2.5)$ \\
\hline $30^{\circ} \mathrm{C}$ & $2.4 \pm 0.7(0.8-3.9)$ & $3.1 \pm 0.3(0-3.4)$ & $1.2 \pm 1(0.2-2.3)$ \\
\hline \multirow[t]{2}{*}{$37^{\circ} \mathrm{C}$} & $0.03 \pm 0.06(0-0.39)$ & $0.06 \pm 0.07(0-0.19)$ & $0.03 \pm 0.06(0-0.17)$ \\
\hline & \multicolumn{3}{|c|}{$\mathrm{CA}$} \\
\hline $6^{\circ} \mathrm{C}$ & $0.57 \pm 0.3(0-1.3)$ & $0.61 \pm 0.2(0.33-0.83)$ & $0.85 \pm 0.3(0.5-1.2)$ \\
\hline $10^{\circ} \mathrm{C}$ & $1.1 \pm 0.6(0.17-2.6)$ & $1.6 \pm 0.17(1.3-1.8)$ & $1.9 \pm 0.2(1.6-2.2)$ \\
\hline $15^{\circ} \mathrm{C}$ & $2.5 \pm 0.6(0.83-3.9)$ & $3.1 \pm 0.2(2.8-3.3)$ & $2.6 \pm 0.3(2-2.9)$ \\
\hline $20^{\circ} \mathrm{C}$ & $3.3 \pm 1.1(1.4-5.4)$ & $4.2 \pm 0.2(4-4.5)$ & $3.4 \pm 0.4(2.9-3.8)$ \\
\hline $25^{\circ} \mathrm{C}$ & $4 \pm 1.3(1.7-7)$ & $2.9 \pm 1.3(1.5-5.2)$ & $3.5 \pm 0.6(2.3-4.1)$ \\
\hline $30^{\circ} \mathrm{C}$ & $4.2 \pm 0.9(2.7-6.1)$ & $4.2 \pm 0.6(3.3-5.1)$ & $3.2 \pm 0.2(2.8-3.4)$ \\
\hline \multirow[t]{2}{*}{$37^{\circ} \mathrm{C}$} & $0.15 \pm 0.14(0-0.75)$ & $0.19 \pm 0.06(0.08-0.25)$ & $0.14 \pm 0.06(0.08-0.25)$ \\
\hline & \multicolumn{3}{|c|}{ V8A } \\
\hline $6^{\circ} \mathrm{C}$ & $0.38 \pm 0.16(0.17-0.75)$ & $0.29 \pm 0.23(0-0.67)$ & $0.56 \pm 0.19(0.33-0.83)$ \\
\hline $10^{\circ} \mathrm{C}$ & $1.4 \pm 0.4(0.75-2.5)$ & $1.6 \pm 0.1(1.4-1.8)$ & $1.8 \pm 0.2(1.5-2.2)$ \\
\hline $15^{\circ} \mathrm{C}$ & $2.5 \pm 0.6(1.7-3.8)$ & $2.9 \pm 0.07(2.8-3)$ & $2.6 \pm 0.07(2.5-2.7)$ \\
\hline $20^{\circ} \mathrm{C}$ & $3.5 \pm 0.7(2.4-5.1)$ & $4 \pm 0.1(3.8-4.2)$ & $3.4 \pm 0.2(3.2-3.7)$ \\
\hline $25^{\circ} \mathrm{C}$ & $4.7 \pm 0.8(2.9-7.1)$ & $5.2 \pm 0.2(5-5.5)$ & $4.6 \pm 0.2(4.3-5)$ \\
\hline $30^{\circ} \mathrm{C}$ & $5.1 \pm 0.6(4.1-6.3)$ & $5.1 \pm 0.7(3.8-5.8)$ & $4.2 \pm 0.1(4-4.3)$ \\
\hline $37^{\circ} \mathrm{C}$ & $0.06 \pm 0.07(0-0.25)$ & $0.15 \pm 0.16(0-0.33)$ & $0.06 \pm 0.07(0-0.17)$ \\
\hline
\end{tabular}

(P245), P. gonapodyides (CBS 117380), and P. cactorum (obtained from rhizosphere of the alder from our own collection) as a pathogen of plants from the Betulaceae Fagaceae and Salicaceae families [23-26] were included in the tests.

The type of hyphae growth of $P$. lacustrtis, incubated for one week in darkness at $25^{\circ} \mathrm{C}$, was determined on Carrot Agar (CA), 20\% non-clarified V8 Juice Agar (V8A), and Potato-Dextrose Agar (PDA). The colony patterns were estimated after one week of incubation in darkness at 6,10 , $15,20,25$, and $30^{\circ} \mathrm{C}$. The experiments were carried out twice, with four replicates per isolate.

The hyphal morphology was observed in microscopic preparations, obtained by suspending colony fragments in water or lactoglycerol at magnifications of 100, 400, and $600 \times$ using a Nikon Optiphot-2 light microscope. Four microscopic slides were taken for each isolate in two replications.

To obtain zoospores, V8 agar overgrown with 10-dayold cultures was cut into pieces of a size of $5 \times 5 \mathrm{~mm}$ and flooded with $1 \%$ non-sterile soil extract. After $24-28$ hours the size of randomly chosen 35 or 25 sporangia (in the first and the second repetition, respectively) was recorded on two microscopic slides for each isolate.

In order to verify whether P. lacustris forms generative organs in contact with other species, agar plugs of colonies of $P$. lacustris were placed on the Petri dishes containing CA medium in pairs with plugs of species, which are usually isolated from water along with $P$. lacustris $-P$. cinnamomi isolates of the A1 and A2 mating types, $P$. cambivora, . gonapodyides, $P$. cactorum, $P$. citrophthora, and $P$. plurivora. The ability to create oogonia and antheridia 

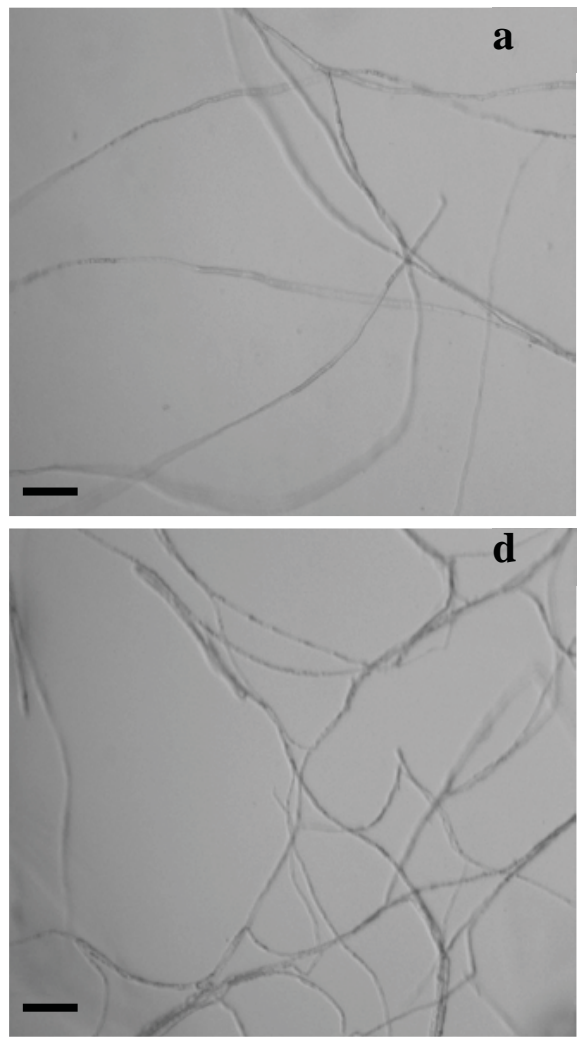
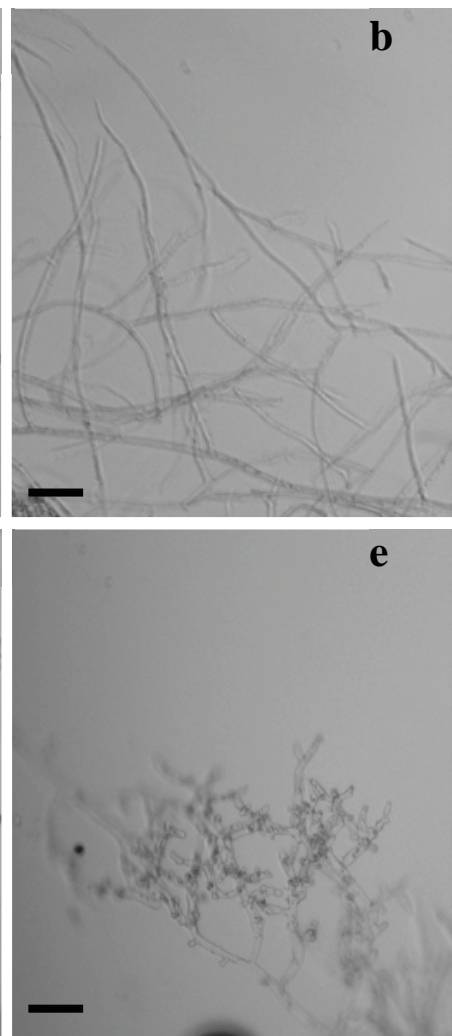

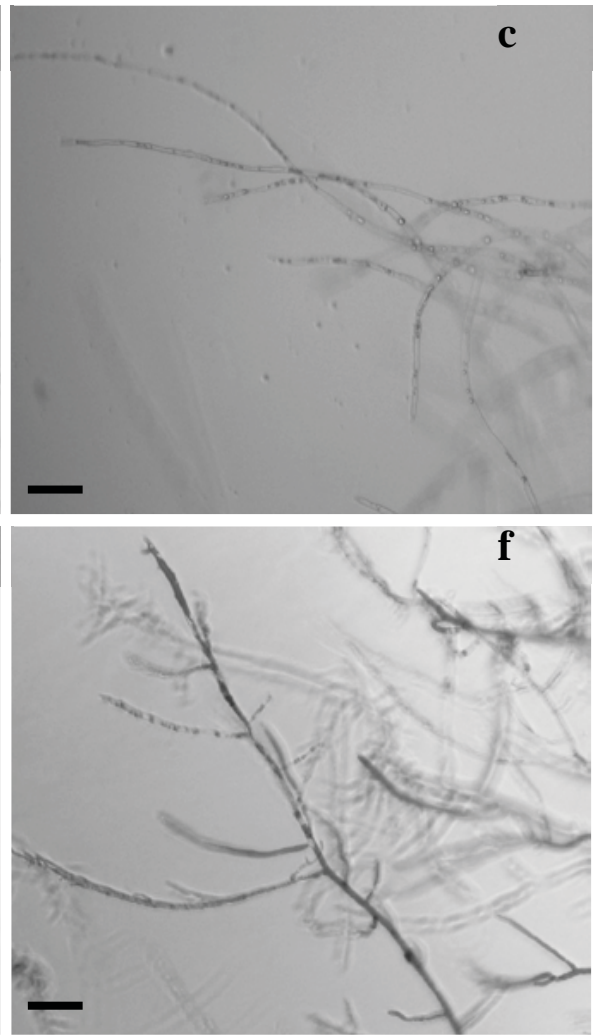

Fig. 4. Morphology of hyphae of P. lacustris grown on CA (a-b) V8A (c-e) and PDA (f). Bar $=60 \mu \mathrm{m}$.
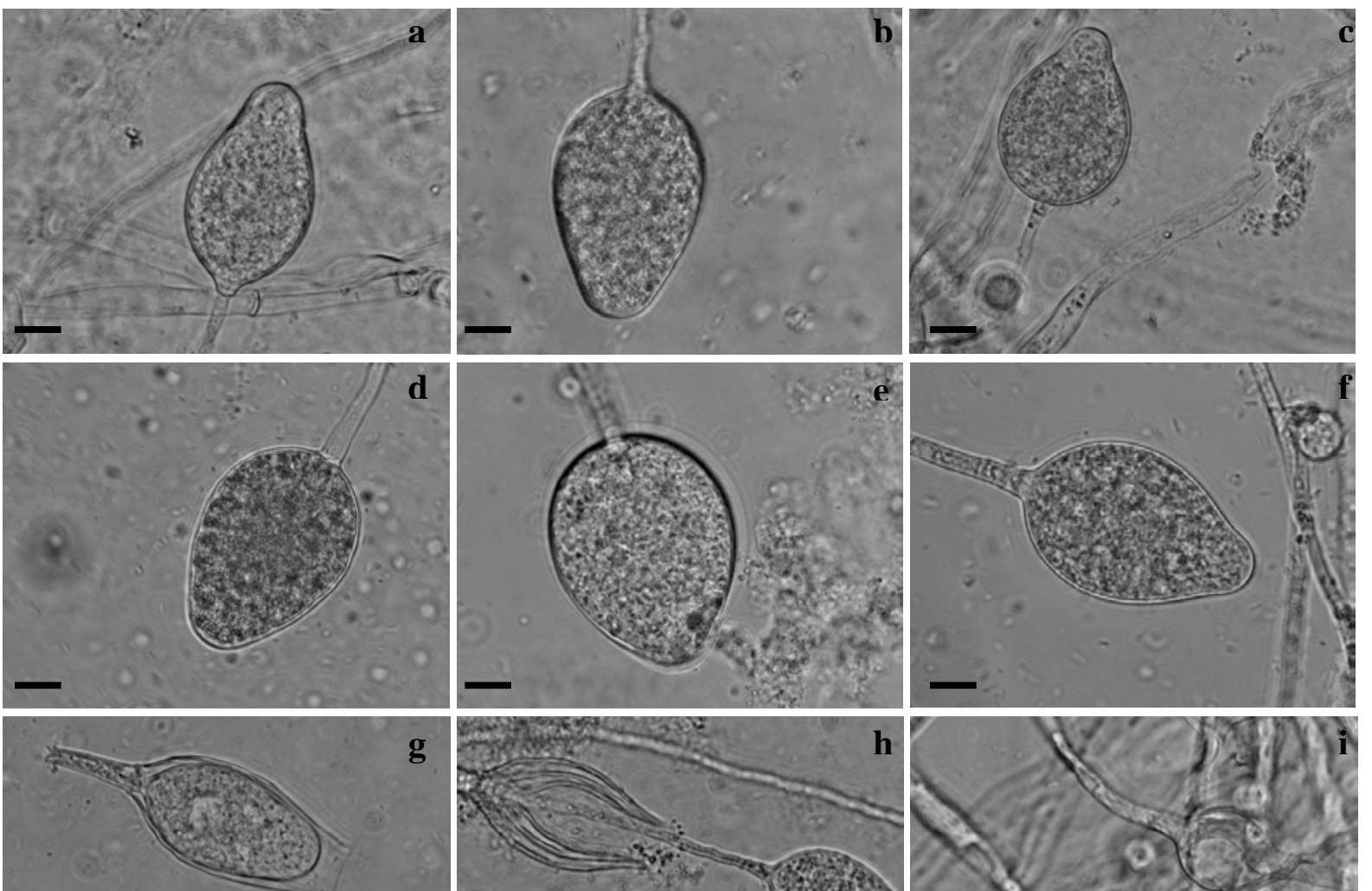

g
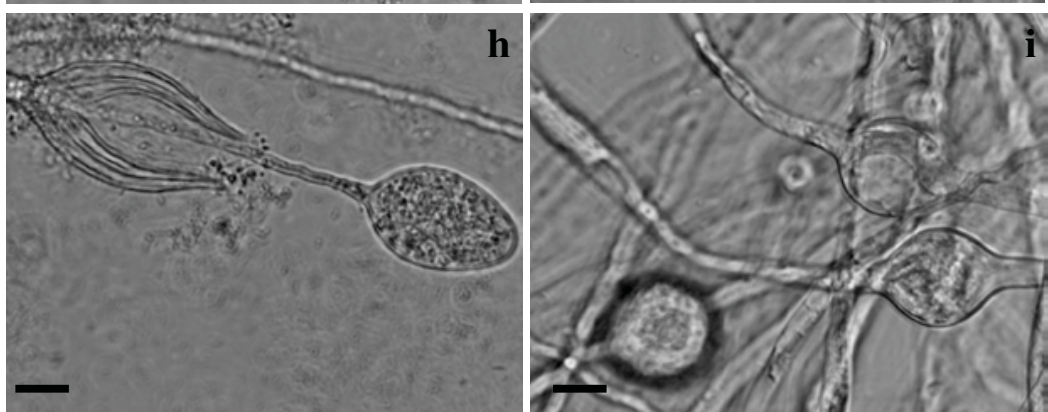

Fig. 5. Shapes of zoosporangia (a-f) and hyphal swellings (i) of P. lacustris. Internal nested (g) and extended (h) proliferation. Bar $=10 \mu \mathrm{m}$. 
was evaluated after 2 and 3 weeks of incubation in the dark at $25^{\circ} \mathrm{C}$. The experiment was repeated twice, with 3 plates for each combination. After incubating the above-mentioned species in pairs, the colony growth was observed for the potential formation of inhibition zones.

The measurements of the daily colony radial growth were carried out on CA, V8A, and PDA media. Mycelial agar plugs of $4 \mathrm{~mm}$, excised from the active growth zone of isolates growing on PDA at $25^{\circ} \mathrm{C}$, were placed in the centre of Petri dishes of $90 \mathrm{~mm}$ diameter. The plates were kept for $24 \mathrm{~h}$ at room temperature $\left(18^{\circ} \mathrm{C}\right)$ in order to initiate the growth processes then incubated in the dark at 6, 10, 15, 20, 25,30 , and $37^{\circ} \mathrm{C}$. The measurement of colony diameter started after $48 \mathrm{~h}$ of isolate growth at a given temperature and was repeated on four consecutive days. The experiments were conducted twice, taking four plates per replication.
To assess the genomic diversity of isolates the polymorphisms between microsatellites (ISSR) and randomly amplified DNA fragments (RAPD) were studied. The isolation of DNA from the pure Phytophthora cultures and PCR conditions were carried out according to the procedures developed previously [27] in a thermal cycler GeneAmp PCR System 9700 (PE Biosystems). DNA fragments were amplified using 14 primers - decamers from Operon: OPX-02, OPX-03, OPX-06, OPX-07, OPX-08, OPX-13, OPX-14-OPZ 14, dodecamers C85 and C92 [28], and ISSR primers (UBC) 808, 827, 889, and 890. The PCR products were separated on $1.4 \%$ agarose gels (SeaKem) at a voltage of about $3 \mathrm{~V} / \mathrm{cm}$ and stained with ethidium bromide. Only the bands within $300-1750$ bp reproducible in 2-3 reactions were qualified for analysis. Their presence or absence was used to prepare a genetic distance matrix using
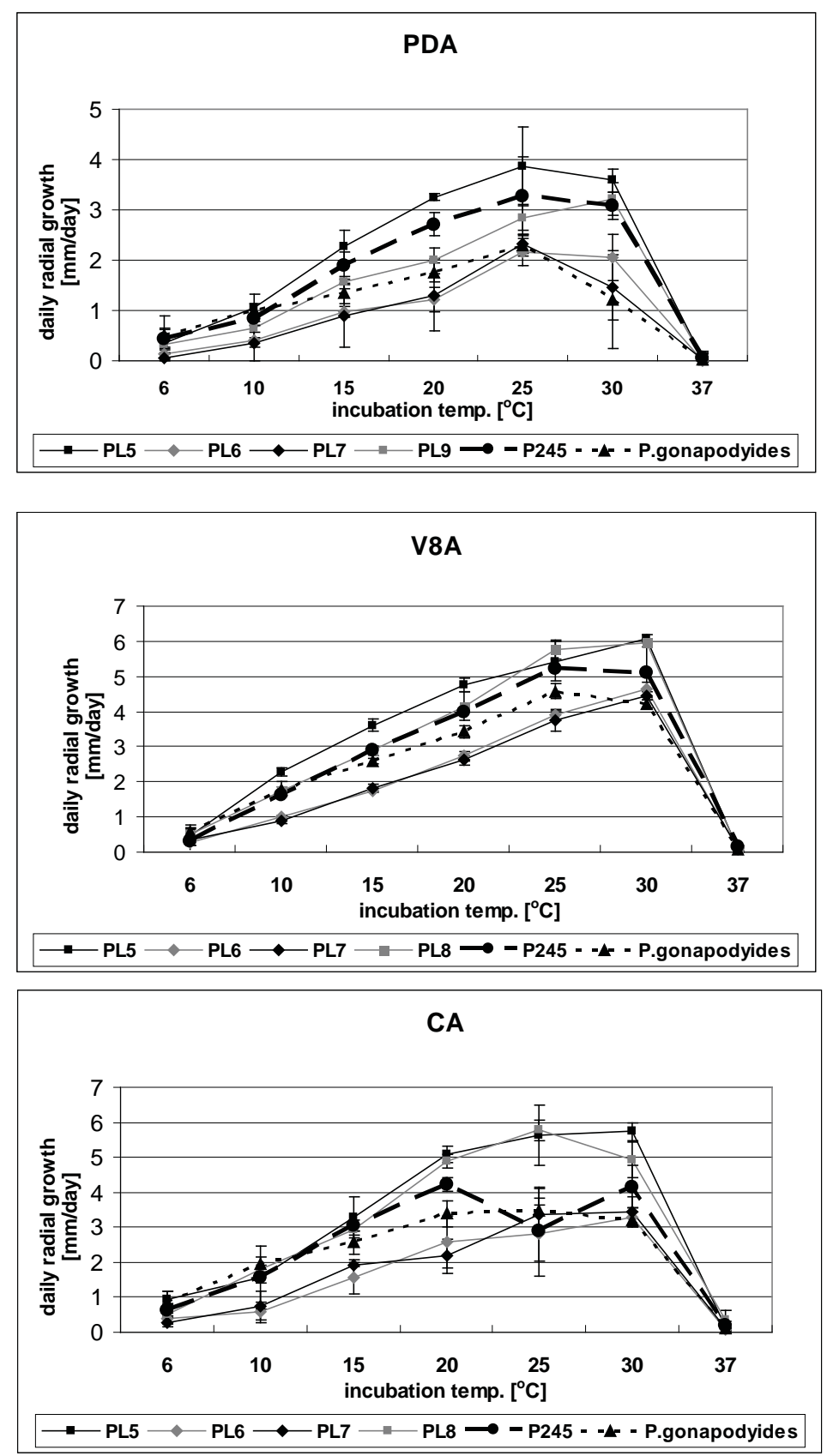

Fig. 6. Mycelium growth of reference and the slowest and the fastest growing P. lacustris isolates depending on temperature and medium \pm SD. 
Restdist program (package PHYLIP 3.695) with the modified coefficient of Nei and Li [29]. Dendrograms were created in accordance with the program TreeView [30], based on the data obtained by UPGMA in the Neighbor (PHYLIP 3.695). To increase the reliability of the constructed tree the bootstrap of 1000-fold multiplication was used.

The ability of 10 selected isolates of $P$. lacustris along with reference isolates to colonize detached young willow leaves and annual shoots of Salix integra 'Pendula' at temperatures of $6,10,15,20,25$, and $30^{\circ} \mathrm{C}$ was investigated. Mycelial plugs overgrown by 7-day old cultures of Phytophthora were placed using a sterile needle on injured leaves near its main nerve and at the base of $7-\mathrm{cm}$ long shoots. As the control, the fragments of non-inoculated medium were taken. The experiment was performed twice. In total, 20 leaves and shoots were inoculated per each isolate. The rate of necrosis formation was observed and the size of necrotic spots on leaves was measured in two directions and averaged and on the stem only length of necrosis was recorded. In order to fulfill Koch's postulates, Phytophthoras were re-isolated from the necrotic tissue resulting from the inoculation and subjected to molecular identification. Small fragments on the border of healthy/necrotic tissue were excized and placed on PDA in order to obtain Phytophthora mycelium. In PCR amplification, identity of DNAs from pure Phytophthora cultures and necrotic plant tissue was confirmed along with DNAs of reference isolates.

Statistical analyses were performed using the STATISTICA 10 package. Mean values of radial growth rates and the size of the necrosis for each temperature were analyzed by the main effects analysis of variance in two-way ANOVA. In some cases, the data compared in the post-hoc Duncan and Dunnett's tests were subjected to Box-Cox transformation in order to normalize the data. Holotypic isolate P245 was used as the control, which was compared with the traits of other isolates.

\section{Results}

\section{Colony Morphology}

Isolates of $P$. lacustris on CA-formed colonies having the hyphae of the substrate type (Fig. 2 a), aerial (Fig. 2 b), and aerial in inoculation site only and the remaining part of

Avereaged mycelial growth

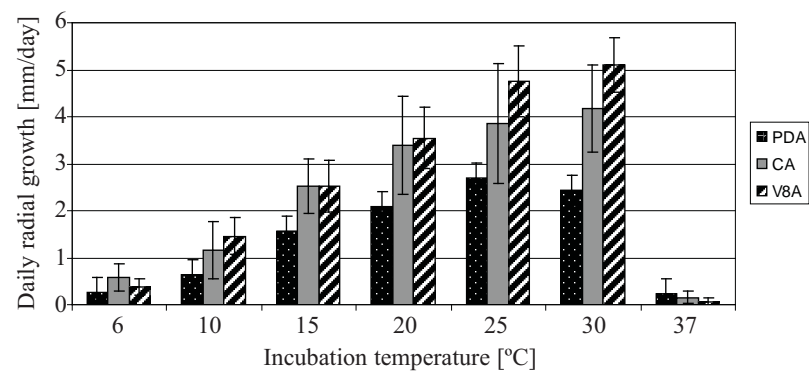

Fig. 7. Averaged daily radial growth of mycelium of 11 isolates (P245 and 10 Polish) depending on medium and temperature \pm SD.

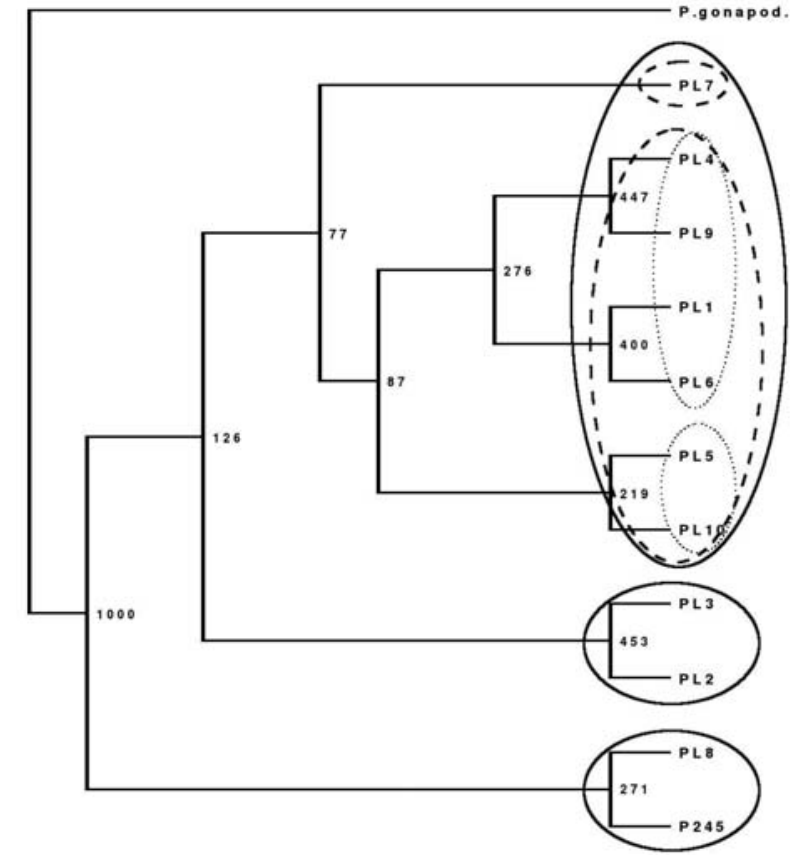

Fig. 8. Cladogram of $P$. gonapodyides and $P$. lacustris isolates based on UPGMA of genetic distance matrix obtained by RAPD and ISSR. Numbers indicate internal node labels.

hyphae was the substrate (Fig. 2 c). Isolates on V8A formed aerial hyphae, whereas on PDA mycelium was more compact and substrate. Colonies were of chrysanthemum-like patterns (Fig. 3 a, e, i), petaloid (Fig. 3 d, h), radiate (Fig. 3 g), stellate (Fig. 3 b, f, j), and sometimes smooth (Fig. 3 c), and intermediate between the above-mentioned (Fig. $3 \mathrm{k}, 1$ ). A greater diversity of colony patterns was observed on V8A and CA media. On PDA, the differences between one-week old isolates predominantly concerned the colony size and substantial differences in morphology of colonies were visible after two weeks of incubation (Fig. 3 i-p). Heterogeneity in the developed colony patterns was also observed between the individual replicates of the same isolate.

\section{Morphology of Structures}

All isolates tested on V8A formed long hyphae without swellings and numerous branching (Fig. 4 a). The exception was the isolate PL6, having a slightly more numerous branching than the rest (Fig. 4 b). On the CA medium all isolates, excluding PL1 and PL10 (Fig. 4 c), were numerously branched ( $4 \mathrm{~d}$ ) and produced long hyphae (Fig. 4 c, d), with the exception of PL7, which produced short (Fig. 4 e), and PL3 and PL4, forming hyphae of a medium length. Isolates cultured on PDA were characterized by shorter and more branched hyphae (Fig. 4 f).

After flooding with non-sterile soil, extract isolates formed simple, single sporangiophores. The shape of the nonpapillate zoosporangia varied - they were ovoid (Fig. 5 d, h), ellipsoidal (Fig. 5 b, g), lemoniform (Fig. 5 c, e), and obpyriform (Fig. 5 a, f). The isolates showed a tendency for internal proliferation and thus intercalary sporangia were 
often observed both nested (Fig. 5 g) and extended (Fig. 5 h), and occasionally also the external proliferation was noted. Average sporangial dimensions of the studied 10 isolates of $P$. lacustris were within the range of 37.2-48.9 $\times 27.2-$ $32.3 \mu \mathrm{m}$ (average of $43.9 \pm 7.3 \times 29.6 \pm 4.9 \mu \mathrm{m}$ ). The mean ratio of length to width was $1.5 \pm 0.2$, with the average range of 1.35-1.72 (Table 1).

Isolates PL2, PL3, PL5, and PL8 in the presence of soil extract produced the abundantly globose or ellipsoid hyphal swellings sized 16-27 × 12-26 $\mu \mathrm{m}$ (Fig. 5 i).

None of the tested $P$. lacustris (inoculated individually and in pairs on plates) formed sexual reproduction organs, also in the presence of $P$. cinnamomi A1 and A2, P. cambivora A1, $P$. citrophthora, $P$. gonapodyides, $P$. cactorum and $P$. plurivora. The presence of $P$. lacustris isolates did not stimulate the production of those organs at A1 and A2 testers of $P$. cinnamomi, and isolates of $P$. cambivora A1, $P$. citrophthora, and P. gonapodyides. After the insightful tests, we found that the two last isolates were sterile.

\section{Colony Daily Growth Rate}

The slowest growth of $P$. lacustris isolates was observed on PDA and the fastest on V8A. We observed significant differences in the growth rates between the isolates, regardless of the medium used. The slowest growth was typical for PL6 and PL7 isolates, while PL5 and PL8 (excepting PDA) grew the fastest (Fig. 6). The largest differences in the growth rates (almost double) were demonstrated at the temperatures 20 and $25^{\circ} \mathrm{C}$, while at extreme temperatures the differences were small, regardless of the medium.

The average growth rates of Polish isolates at the optimal range of growth temperatures on V8A, CA, and PDA were at $25^{\circ} \mathrm{C}: 4.7 \pm 0.8,4 \pm 1.3$ and $2.7 \pm 0.6 \mathrm{~mm} /$ day, respectively and at $30^{\circ} \mathrm{C}: 5.1 \pm 0.6,4.2 \pm 0.9$ and $2.4 \pm 0.7$ $\mathrm{mm} /$ day, respectively. The average and extreme (minimal and maximal) values of the daily radial growth rates for individual isolates are listed in Table 2.

Isolates of $P$. lacustris did not form inhibition zones on the medium when inoculated in pairs with other species of Phytophthora. Those isolates, which grew faster, occupied the same surface of the medium as the first.

\section{Growth Temperature Range}

Mycelium growth of the tested isolates was observed within the temperature range from 6 to $37^{\circ} \mathrm{C}$ (Fig. 7). The growth optimum of most isolates on CA and V8A was at $30^{\circ} \mathrm{C}$, while on PDA medium only PL9 isolate had its growth optimum at $30^{\circ} \mathrm{C}$ and the rest at $25^{\circ} \mathrm{C}$ (Fig. 6).

\section{Genomic Diversity Assessment}

Ninety bands out of 106 obtained from the amplification of $P$. lacustris DNA were polymorphic (84.9\%). For a common pool of isolates $-P$. lacustris and $P$. gonapodyides, 127 fragments were obtained, out of which 122 (96.1\%) showed polymorphism. Among them, 21 (16.5\%) DNA fragments were specific only to $P$. gonapodyides and 11
(8.7\%) were common for all the isolates of P. lacustris, and absent in $P$. gonapodyides.

Phylogenetic analysis revealed genomic heterogeneity of the tested isolates (Fig. 8). Three clades were separated: first - formed by PL2 and PL3 isolates, second - by PL8 and P245, and the third was divided into two subclades: one contained only PL7 isolate and the rest $-P$. lacustris isolates in the second subclade. However, considerable differences in genetic distances are shown among the isolates of this subclade and also genetically closely related pairs PL5 and PL10, and the groups of pairs PL6/PL1 and PL9/PL4 can be separated.

\section{Colonization Ability Assessment}

Lack of necrosis was noticed on the control leaves and shoots. Individual isolates of $P$. lacustris caused the necrotic spots formation of size dependent on incubation temperature. The smallest spots occurred at $6^{\circ} \mathrm{C}$, and the largest at $30^{\circ} \mathrm{C}$ (Fig. 9). On the fourth day after inoculation, the tendency to form the biggest spots on the leaves was observed with PL4, PL1, and PL5 isolates and, at lower temperatures, often with PL3. The smallest ones were caused by PL6 and PL7 isolates. P245 isolate caused necroses of the intermediate size, whereas $P$. cactorum and $P$. gonapodyides caused necrotic spots much smaller than the isolates of P. lacustris (Fig. 10).

On the fourth day after inoculation, the biggest shoot necrosis were caused by PL4, PL5, and PL8 isolates, and
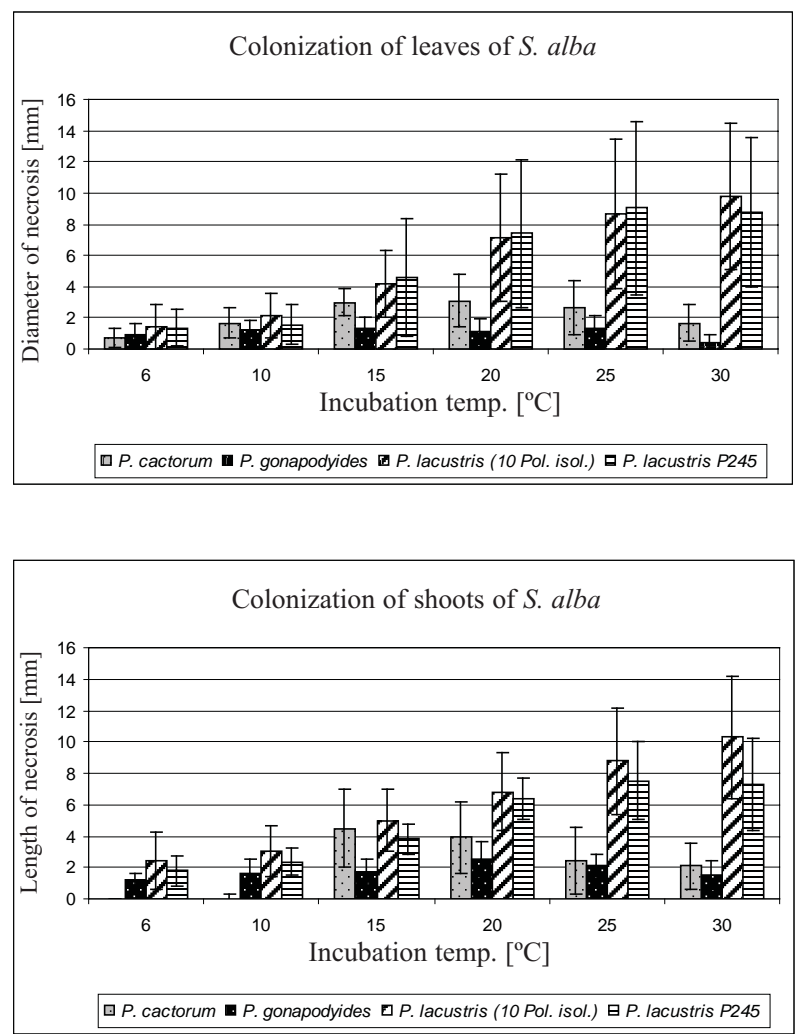

Fig. 9. Temperature-dependent colonization abilities of $P$. lacustris (10 Polish and P245), P. gonapodyides, and P. cactorum isolates illustrated as necroses of $S$. alba tissue on the fourth day after inoculation $\pm \mathrm{SD}$. 
often by PL3. The slowest colonization of willow one-year shoots was observed for P. cactorum and P. gonapodyides, and in P. lacustris isolates of PL9, PL7, and PL6. P245 isolate showed an intermediate ability to colonize the shoots.

The presence of $P$. lacustris, $P$. cactorum, and $P$. gonapodyides in necrotic tissues was confirmed by PCR with the re-isolated Phytophthoras.

\section{Discussion}

A great interest in P. lacustris is associated with its mass isolation from necrotic fragments of plants, plant debris, water, and sludge at different latitudes [4]. It is often isolated together with $P$. gonapodyides from humid environments, mostly from natural habitats $[6,9,11,13,14,31,32]$, but less often from fruit and ornamental nurseries [10, 21, 33].

This ubiquity leads to the question of the role this species plays in nature. Until recently, the Phytophthora species were considered as primary pathogens [34]. Now, a large group of species is considered saprophytes, which are involved in the breakdown of plant debris and occasionally may cause local plant necrosis $[4,11,35,36]$. P. lacustris has never been recognized as a main agent of dieback of trees and shrubs in the environment, although its isolates were obtained from necrotic stem bases and necrotic roots of 60-year-old trees of Fraxinus excelsior showing advanced Phytophthora rot symptoms [8], from dead
Prunus plants from a nursery [33], or from the soil sampled around diseased 100-year-old ash trees [36]. Isolates of $P$. lacustris are able to colonize leaves, shoots, and fine roots [4, 8, 18, 37, 38]

The saprophytic character of $P$. lacustris speaks to great diversity in colony patterns, growth rates, and size of the zoospores, as well as DNA polymorphism within the ITS fragments and coxl [4] and within microsatellite DNA locus S29-30 [20]. Our studies confirmed the above reports; isolates of $P$. lacustris formed colonies of different patterns on tested media and at the same temperature. The holotype of the species, P245 isolate, did not stand out in features that could be considered model ones. In general, the daily colony growth rate and the size of necrotic spots of this isolate had intermediate values in our study population. It cannot be said that one of the isolates studied here was particularly similar to P245. Only analyses of ISSR and RAPD fragments revealed molecular similarity of PL8 to P245, but statistical Dunnet's tests of other tested features often showed significant differences between those isolates.

The colony's morphology of the isolates studied here varied from chrysanthemum-like, petaloid, radiate, stellate, and sometimes smooth to intermediate between these types within the tested isolates. Nechwatal et al. [4] observed only very similar petaloid or chrysanthemum-like patterns, although studied isolates originated from different environments and countries. Similar to the studies of those authors [4], P. lacustris hyphae in our study were more dense and
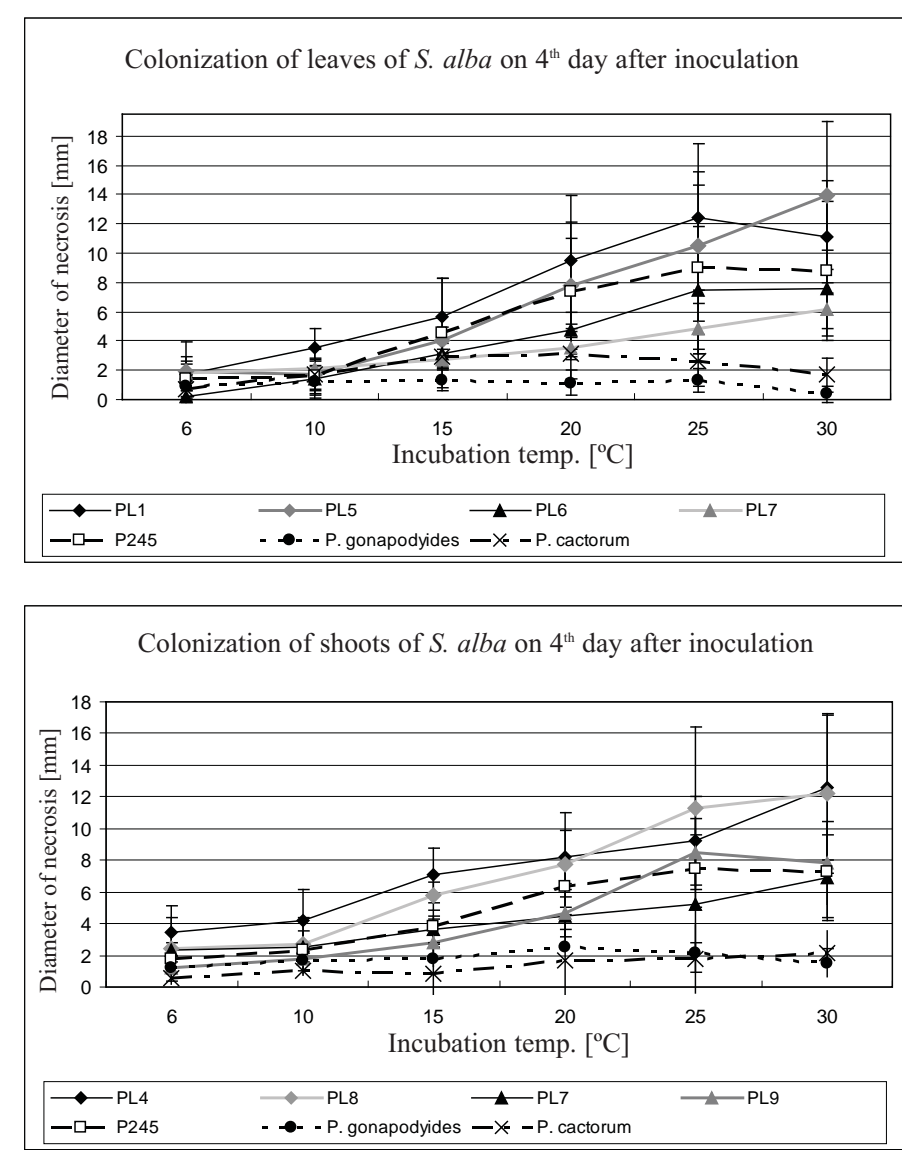

Fig. 10. Size of necroses of leaves and stems of $S$. alba observed on the fourth day after inoculation with P. gonapodyides, P. cactorum, and P. lacustris (P245 and Polish isolates showing extreme values) $\pm \mathrm{SD}$. 
substrate on PDA and larger and more loose and aerial on V8A and CA.

Also, in the the case of the morphology of vegetative structures, differences between the individual isolates were observed. The shapes and sizes of sporangia and hyphae varied within the studied population. Some isolates of P. lacustris showed the tendency to form hyphal swellings.

A formation of generative organs was not observed as the effect of mating of the tested $P$. lacustris isolates with $\mathrm{A} 1$ and $\mathrm{A} 2$ testers of $P$. cinnamomi, which confirms the studies of Brasier et al. [39]. In our studies, sexual reproduction organs of $P$. lacustris were also not formed in the case of matings with $P$. cambivora A1, $P$. cactorum, and $P$. plurivora. They also were not obtained by other authors in a wide range of matings of $P$. lacustris with $P$. palmivora, $P$. cryptogea, P. drechsleri, P. cambivora, P. capsici, $P$. megakarya, and $P$. meadii; however, A2 testers of the last five species formed reproductive organs in the presence of P. lacustris [4, 18, 39].

Isolates showed differences in the daily growth rates, regardless of the type of medium but dependent on temperature. Similarly as in Nechwatal et al. [4] studies, differences between growth rates of our isolates were significant. The slowest growth of $P$. lacustris isolates was observed on PDA and the fastest on V8A. In studies of Nechwatal et al. [4] P. lacustris grew faster on CA. This discrepancy is probably due to the differences in the way of preparing of V8A media. In our laboratory V8 Juice Agar is being used in non-clarified form, whereas Nechwatal et al. carried out tests on clarified V8A (cV8A). Moreover, the infuence of origin of V8 Juice on the properties of medium should be taken into account.

P. lacustris differs from the phenotypically closest $P$. gonapodyides in its temperature requirements. Whereas the optimal and maximal temperatures for $P$. lacustris was 28 to $33^{\circ} \mathrm{C}$ and 36 to $37^{\circ} \mathrm{C}$, for the $P$. gonapodyides 25 and $34^{\circ} \mathrm{C}$, respectively [4]. In our study, the optimal temperature for $P$. lacustris depended on medium composition because PDA it was mainly $25^{\circ} \mathrm{C}$ and on $\mathrm{V} 8 \mathrm{~A}$ and $\mathrm{CA} 30^{\circ} \mathrm{C}$. Nechwatal et al. [4] tested 14 P. lacustris isolates and obtained growth optimum at range $28-33^{\circ} \mathrm{C}$. Our preliminary tests conducted on 38 of 114 Polish isolates growing on PDA at $25,28,30$ and $32^{\circ} \mathrm{C}$ revealed that $55.9 \%$ had growth optimum at $25^{\circ} \mathrm{C}$, whereas $35.3 \%$ and $8.8 \%$ had optima at 28 and $30^{\circ} \mathrm{C}$, respectively, and none of them at $32^{\circ} \mathrm{C}$ (data not shown). This may suggest that individuals belonging to this species are more diversified than has yet been elucidated.

In our studies, the lowest tested temperature enabling colony growth was $6^{\circ} \mathrm{C}$, so we cannot confirm an ability to grow at lower temperatures as reported by Nechwatal et al. [4]. All isolates terminated growth at $37^{\circ} \mathrm{C}$. P. gonapodyides grew always slower in optimal temperatures than the quickest $P$. lacustris isolate and P245.

The isolates also differed in the rate of colonization of the willow leaves and stems. We found a positive correlation between the growth rate on the medium and the rate of plant tissue colonization, demonstrated by the size of necrotic spots. It seems to be an interesting observation, that general linear models analysis of the bulk data at all temperatures tested showed an inverse proportionality of the zoospore size produced by the tested isolates to their growth rate on media (and thus - also to the colonization speed of the infected tissue).

There was no correlation between the physiological and morphological characteristics and the phylogram groups formed based on the genetic distance matrix of patterns generated by RAPDs and ISSRs. In phylogenetic studies Nechwatal et al. [4] analyzed the sequences of nuclear and mitochondrial DNA (ITS and $\operatorname{cox} 1$ ) of $P$. lacustris isolates obtained from Europe, the United States, Australia, and New Zealand. They also revealed the differences between isolates, but they did not find any linkage to their geographical origin and concluded $P$. lacustris as a monophyletic taxon, with contradictions concerning specific locations of the branch of the species in Clade 6 $[4,7,11]$. Such a large morphological, physiological, and genomic diversity of traits of $P$. lacustris may suggest that this species uses a variety of food sources. Also, its ubiquity in aquatic habitats implies its saprotrophic character.

Among various screening methods of $P$. lacustris pathogenicity, a test based on the inoculation of the substrate with zoospores, under a high moisture level, or on the roots flooded by inoculated water that likely occur under natural conditions seems to be the most appropriate. However, in those tests the roles of micro environmental factors and genetic differences between seedlings are very important. It causes differences between inoculated and control plants to be not statistically significant, although they are large in absolute terms [38]. In Navarro's assays [38] only the necroses limited to the small roots were statistically proven. Full disease development and plant dieback resulted from artificial inoculation with P. lacustris were obtained episodically [4]. In the pathogenicity tests carried out on the one-year-old shoots of Alnus glutinosa and Salix alba the inoculation with P. lacustris resulted in the formation of larger spots than those after inoculation with $P$. gonapodyides $[4,38]$. In our test the isolates of $P$. lacustris also colonized shoots and leaves of willow to a greater degree than $P$. cactorum and $P$. gonapodyides.

Based on pathogenicity tests, P. lacustris cannot be considered as the obligatory pathogen. However, it can facilitate the tissue colonization by other pathogens by destroying the young roots and weakening the plant. The experiments studying such a process should be long lasting. Soil-borne Phytophthora diseases generally develop for many years, and first symptoms appear after exposure of plants to additional unfavorable factors such as flooding, which weakens plants but promotes the abundant release of zoospore, thereby increasing root colonization, followed by drought, when damaged small roots are not able to supply water $[4,33]$.

Although $P$. lacustris was isolated from necrotic roots and it was found to be a causal agent of the surface necrosis of shoots, the statement that $P$. lacustris is the main cause of Phytophthora rot or plants dieback is unauthorized. Another aspect for explaining the yet unknown role of such ubiquitous microorganisms in the soil and water may be 
their dominant character through which they behave like weeds. The following characteristics could speak to the high competition among microorganisms: an exceptional vigor and number of propagules, no special requirements to nutrition, efficient nutrient acquisition, high tolerance to diverse stresses, production of stressful or toxic metabolites for other microorganisms, and more [40].

$P$. lacustris, as other species of ITS Clade 6 as well as wetland plants, are well adapted to aquatic environments and to mutual co-existence, which enables them to live together without parasitism. A very different situation may occur when the microorganisms from homely wetlands inhabit with the irrigation water from rivers or ponds an agricultural environment, and if cultivated there plants are not resistant to them $[4,10]$. A similar situation may occur when any alien species inhabits cultivated plants or a natural environment. Several species can also behave as opportunistic pathogens, attacking weakened plants, which can happen as a result of flooding and/or drought.

Therefore, for a proper assessment of the potential threat posed by $P$. lacustris in the natural stands and on plantations of cultivated plants, long-term, exceeding oneyear observations of the plants inoculated with zoospores should be conducted.

\section{Acknowledgements}

The authors would like to express thanks to Prof. R. Maciorowski for statistical consultation.

\section{References}

1. PARK J., PARK B., VEERARAGHAVAN N., JUNG K., LEE Y.-H., BLAIR J.E., GEISER D. M., ISARD S., MANSFIELD M. A., NIKOLAEVA E., PARK S.-Y., RUSSO J., KIM S.H., GREENE M., IVORS K. L., BALCI Y., PEIMAN M., ERWIN D.C., COFFEY M.D., ROSSMAN A., FARR D., CLIN, E., GRÜNWALD N.J., LUSTER D. G., SCHRANDT J., MARTIN F., RIBEIRO O.K., MAKALOWSKA I., KANG S. Phytophthora Database: A forensic database supporting the identification and monitoring of Phytophthora. Plant Dis., 92, 966, 2008.

2. GRÜNWALD N.J., MARTIN F.N., LARSEN M.M., SULLIVAN C.M., PRESS C.M., COFFEY M.D., HANSEN E.M., PARKE J.L. Phytophthora-ID.org: a sequence-based Phytophthora identification tool. Plant Dis. 95, 337, 2011.

3. MARTIN F.N., BLAIR J.E., COFFEY M.D. A combined mitochondrial and nuclear multilocus phylogeny of the genus Phytophthora. Fungal Gen. Biol., 66, 19, 2014.

4. NECHWATAL J., BAKONYI J., CACCIOLA S.O., COOKE D.E.L., JUNG T., NAGY Z.A., VANNINI A., VETTRAINO A.M., BRASIER C.M. The morphology, behavior and molecular phylogeny of Phytophthora taxon Salixsoil and its redestination as Phytophthora lacustris sp. nov. Plant Pathol. 62, 355, 2013.

5. NECHWATAL J., MENDGEN K. Widespread detection of Phytophthora taxon Salixsoil in the littoral zone of Lake Constance, Germany. Eur. J. Plant Pathol. 114, 261, 2006.
6. REESER P.W., SUTTONW., HANSEN E.M., REMIGI P., ADAMS G.C. Phytophthora species in forest streams in Oregon and Alaska. Mycologia 103, 22, 2011.

7. JUNG T., STUKELY M.J.C., HARDY G.E.ST.J., WHITE D., PAAP T., DUNSTAN W.A., BURGESS T.I. Multiple new Phytophthora species from ITS Clade 6 associated with natural ecosystems in Australia: evolutionary and ecological implications. Persoonia 26, 13, 2011.

8. ORLIKOWSKI L.B., PTASZEK M., RODZIEWICZ A., NECHWATAL J., THINGGAARD K., JUNG T. Phytophthora root and collar rot of mature Fraxinus excelsior in forest stands in Poland and Denmark. Forest Pathol. 41, 510, 2011.

9. ORLIKOWSKI L.B., TRZEWIK A., PTASZEK M., TUŁACZ D. Water as a source of Phytophthora spp. and their threat to growing plants. Prog. Plant Prot. 52, (3), 646, 2012 [In Polish].

10. DAS A.K., NERKAR S.G., BAWAGE S.S., KUMAR A. First report of Phytophthora lacustris in India. J. Plant Pathol. 95, (2), 447, 2013.

11. BRASIER C.M., COOKE D.E.L., DUNCAN J.M., HANSEN E.M. Multiple new phenotypic taxa from trees and riparian ecosystems in Phytophthora gonapodyides - $P$. megasperma ITS Clade 6, which tend to be high-temperature tolerant and either inbreeding or sterile. Mycol. Res. 107, 277, 2003

12. ZAPPIA, R.E., HÜBERLI, D., HARDY G.E.ST.J., BAYLISS K.L. Fungi and oomycetes in open irrigation systems: knowledge gaps and biosecurity implications. Plant Patol., Doi: 10.1111/ppa.12223, 2014

13. HANSEN E., REESER P., SUTTON W., SIMS L. Host and habitat index Phytophthora species in Oregon. Forest Phytophthoras 2, 1, 2012.

14. SHRESTHA S.K., ZHOU Y., LAMOUR K. Oomycetes baited from streams in Tennessee 2010-2012. Mycologia 105, 1516, 2013.

15. JONES L.A., WOROBO R.W., SMART C.D. PlantPathogenic Oomycetes, Escherichia coli Strains, and Salmonella spp. frequently found in surface water used for irrigation of fruit and vegetable crops in New York State. Appl. Environ. Microbiol., 80, (16), 4814, 2014.

16. SCIBETTA S., SCHENA L., CHIMENTO A., CACCIOLA S.O., COOKE D.E.L. A molecular method to assess Phytophthora diversity in environmental samples. J. Microbiol. Meth. 88, 356, 2012.

17. HUAI W.-X., TIAN G., HANSEN E.M., ZHAO W.-X., GOHEEN E.M., GRÜNWALD N.J., CHENG C. Identification of Phytophthora species baited and isolated from forest soil and streams in Northwestern Yunnan province, China. For. Path. 43, 87, 2013.

18. TELFER K.H. A survey of Phytophthora in beech forest in Norway. Master thesis at Norvegian Univ. of Life Sci., pp. 1-60, 2014.

19. MATISAKH I., KRAMARETS V., ORLIKOWSKI L.B., TRZEWIK A. First report on Phytophthora spp. and Pythium litorale occurrence in Beskid's rivers (of the Ukrainian Carpathians). Prog. Plant Prot., 52, (4), 1200, 2012 [in Polish].

20. NOWAKOWSKA J.A., OSZAKO T., BORYS M., SIKORA K., KUBIAK K., OLEJARSKI I. Genetic variability of Phytophthora community in natural water resources assessed with microsatellite DNA markers. Balic Forestry 18, (1), 2019, 2012.

21. ORLIKOWSKI L.B., MESZKA B., PTASZEK M., TRZEWIK A., ORLIKOWSKA T. A threat to the environ- 
ment and horticultural plants posed by new Phytophthora species isolated from water. Water-Environment-Rural Areas 12, (3), 171, 2012 [In Polish].

22. THEMANN K., WERRES S., LÜTTMANN R., DIENER H.A. Observations of Phytophthora spp. in water recirculation systems in commercial hardy ornamental nursery stock. E. J. Plant Pathol. 108, 337, 2002.

23. OSZAKO T., ORLIKOWSKI L.B., TRZEWIK A. Menace to Polish forest nurseries by Phytophthora species. Progress in Plant Prot. 47, (2), 224, 2007 [In Polish].

24. ČERNY K., STRNADOVA V., GREGOROVA B., HOLUB V., TOMSOVSKY M., MRAZKOVA M., GABRIELOVA S. Phytophthora cactorum causing bleeding canker of common beech, horse chestnut, and white poplar in the Czech Republic. Plant Pathol. 58, 394, 2009.

25. HOLUB V., ČERNÝ K., STRNADOVÁ V., MRÁZKOVÁ M., GREGOROVÁ B., GABRIELOVÁ Š. The survey of some factors affecting bark lesion development caused by Phytophthora cactorum on common beech and other broadleaved trees. J. Forest Sci. 56, (3), 93, 2010.

26. HANTULA J., LILJA A., PARIKKA P. Genetic variation and host specifity of Phytophthora cactorum isolated in Europe. Mycol. Res. 101, (5), 565, 1997.

27. WIEJACHA K., SZKUTA G., ORLIKOWSKA T. Optimization of DNA isolation procedure as the first step in identification of Phytophthora spp. Bull. Pol. Acad. Sci. 50, (Biol. Sci. 3), 165, 2002.

28. LEE J.S., LEE P.O., ROH M.S. Classification of lilies using Random Amplified Polymorphic DNA (RAPD) analysis. Acta Hort. 414, 137, 1996.

29. FELSENSTEIN J. PHYLIP (Phylogeny Inference Package) version 3.6. Distributed by the author. Department of Genome Sciences, University of Washington, Seattle. 2005.

30. PAGE R.D.M. TREEVIEW: An application to display phylogenetic trees on personal computers. Computer Applic. Biosci. 12, 357, 1996.
31. JUNG T., NECHWATAL J. Phytophthora gallica sp. nov., a new species from rhizosphere soil of declining oak and reed stands in France and Germany. Mycol. Res. 112, $1195,2008$.

32. SZABÓ I., LAKATOS F., SIPOS G. Occurrence of soilborne Phytophthora species in declining broadleaf forests in Hungary. Eur. J. Plant Pathol. 137, 159, 2013.

33. CACCIOLA S.O., WILLIAMS N.A., COOKE D.E.L., DUNCAN J.M. Molecular identification and detection of Phytophthora species on some important Mediterranean plants including sweet chestnut. Forest Snow and Landscape Res. 76, 351, 2001

34. ERWIN D.C., RIBEIRO O.K. Phytophthora Diseases worldwide, APS Press, St. Paul., pp. 1-592, 1996.

35. HANSEN R., DELATOUR C. Phytophthora species in oak forests of north-east France. Ann. For. Sci. 56, 539, 1999.

36. BRASIER C.M., SANCHEZ-HERNANDEZ E., KIRK S.A. Phytophthora inundata sp. nov., a part heterothallic pathogen of trees and shrubs in wet or flooded soils. Mycol. Res. 107, 477, 2003.

37. AKILLI S., ULUBAŞ SERÇE Ç., KATIRCIOĞLU Y. Z.MADEN S. Phytophthora dieback on narrow leaved ash in the Black Sea region of Turkey. Forest Pathol. 43, (3), 252, 2013

38. NAVARRO S.M. Pathogenicity of Phytophthora species from Oregon waterways. Oregon State Univ., Master Thesis, pp. 1-109, 2013.

39. BRASIER C.M., HAMM P.B., HANSEN E.M. Cultural characteristics, protein patterns and unusual mating behavior of Phytophthora gonapodyides isolates from Britain and North America. Mycol. Res. 97, 1287, 1993

40. CRAY J.A., BELL A.N.W., BHAGANNA P., MSWAKA A.Y., TIMSON D.J., HALLSWORTH J.E. The biology of habitat dominance; can microbes behave as weeds? Microbial Biotechnol. 6, 453, 2013. 